\title{
The Effect of Apparatus Competence on the Quality of Local Government Financial Reports with the Utilization of Information Technology as Intervening Variable: Survey on Regional Apparatus Organizations of Donggala Government
}

\author{
Neni Kasmawati ${ }^{*}$, Ridwan², Muhammad Din ${ }^{2}$, Nina Yusnita Yamin², Rahma \\ Masdar $^{2}$, Jurana NS ${ }^{2}$, Saparman ${ }^{3}$ \\ ${ }^{1}$ Student of Accounting Department, Tadulako University, Palu, Indonesia \\ ${ }^{2}$ Lecturer in Accounting Department, Tadulako University, Palu, Indonesia \\ ${ }^{3}$ Lecturer in Accounting Department, College of Economics, Palu, Indonesia \\ *Corresponding author.Email: neni.nenikasmawati@gmail.com
}

\begin{abstract}
This study aims to examine the effect of apparatus competence on the quality of regional reports by using information technology as an intervening variable in the Donggala Regency Government. This research is a survey research, using quantitative research methods and primary data. The population in this study were all regional apparatus organizations in Donggala Regency. The respondents were the leaders of the sample. By using purposive sampling, the sample was 44 respondents. The results indicate that the competence of the apparatus has a significant effect on the quality of financial reports through the use of information technology and the apparatus competence has a partial effect on the quality of financial reports.
\end{abstract}

Keywords: Apparatus Competence, Information Technology, Quality of Financial Reports.

\section{INTRODUCTION}

The quality of government financial reporting is influenced by apparatus competence and the use of information technology. [1] states that information technology has benefits or convenience for someone to save time and energy. In order to optimize regional management, currently, BPK and BPKP have developed applications that can help facilitate employees in the form of the Regional Management Information System (SIMDA). The objectives of SIMDA are to (1) provide an integrated database of conditions in the regions, starting from the aspects of staffing, regional assets, finances to public services; (2) produce a comprehensive, precise, and accurate information to local government management that can be used for decision making; (3) prepare regional officials to be able and capable of mastering and using information technology; and (4) strengthen the basis of regional government for the implementation of regional autonomy.

The SIMDA used for data input is still based offline, so that data input can only be done at work (office). But as technology develops, offline-based SIMDA applications can be online into E-Finance. The difference between SIMDA and E-Finance only lies in the network connection, while the data input process remains the same.

In 2018, the head of the BPK explained that the results of the 2018 Donggala LKPD examination found weaknesses and compliance problems. BPK found weaknesses in the internal control system and financial compliance required by laws and regulations. More specifically, weaknesses in the management of regional cash and assets and weaknesses in managing 
the procurement of goods and services were found. As for compliance records, it was found that there were jobs that were not the same as the contract specifications or lacked volume as well as problems with the price of work and excess financing for construction work [2]. This research is important to do to find out the quality of the information produced by the Donggala Regency Government. The reason the researcher took the place of research in Donggala Regency is because Donggala Regency is one of the areas that received Qualified Opinion (WDP) in recent years, from 2016 to 2018 .

\section{LITERATURE REVIEW}

\subsection{Apparatus Competence and Utilization of Information Technology on the Quality of Financial Reports}

Financial reports are a form of accountability carried out by the government in managing regional wealth. Research conducted by [3] and [4] suggests that there are several factors that affect the quality of financial reports. These factors include the competence of human resources (apparatus) and the use of information technology. In improving the quality of financial reports, human resources (apparatus) are needed who have competence in the form of knowledge in the field of accounting [5], [6]. Research conducted by [7] shows that the competence of the apparatus has an effect on the quality of financial reports. [8] showed that the use of information technology had an effect on the quality of financial reports. [9] showed that the competence of the apparatus and the use of information technology have a significant effect on the quality of financial reports. This is in line with research conducted by [10] and [11] with the results that the competence of human resources as apparatus and supported by the application of regional management information systems can improve the quality of financial reports. So, the relationship is hypothesized as follows:

H1: Apparatus competence has a significant effect on the quality of local government financial reports with the use of information technology as an intervening variable

\subsection{Relationship between Apparatus Competence and Utilization of Information Technology}

The use of information technology is known to have advantages in terms of accuracy, consistency, speed, reliability and the ability to store large data. Research conducted by [12] stated that the main roles of information technology systems in organizations are to increase efficiency, effectiveness, communication, collaboration, and competitiveness. Judging from the role and objectives in the application of information technology, various forms of available information technology applications are utilized by offices to speed up the processing of financial statements properly. [10] stated that the higher the use of information technology, the higher the quality of financial reports. Vice versa, if the use of information technology decreases, the quality of local government financial reports will also decrease.

H2: Apparatus competence partially affects the use of information technology

\subsection{The Relationship between the Utilization of Information Technology on the Quality of Financial Reports}

Research conducted by [12] stated that the main roles of information technology systems in organizations are to increase efficiency, increase effectiveness, improve communication and collaboration, and increase competitiveness. Based on the roles and objectives of the application of information and communication technology, various forms of available information and communication technology applications are utilized by offices to speed up the processing of financial statements properly. [10] measures the use of information technology based on the instrument adopted by [13] with the number of question items being 8 items with a 5-point Likert scale. The research used the indicators to measure the technology utilization variables including the equipment, management and storage of financial and maintenance data. The results empirically proved that the use of information technology affects the quality of local government financial reports. The higher the utilization of information technology, the better the quality of financial reports. On the other hand, if the use of information technology decreases, the quality of local government financial reports will also decrease.

H3: Information technology partially affects the quality of regional financial reports.

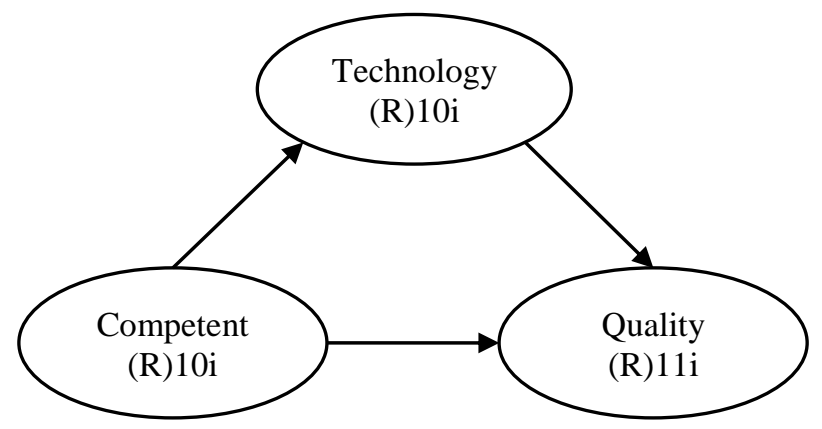

Figure 1 Theoretical Framework 


\section{RESEARCH METHODS}

\subsection{Research Object}

The objects in this study are the competence of the apparatus, the use of information technology, and the quality of financial reports in Donggala Regency (Figure 1). This research was conducted on Regional Apparatus Organizations in Donggala Regency.

\subsection{Research Type}

This type of research is a survey, which is a technique of collecting information by compiling a list of statements to be submitted to respondents.

\subsection{Data Type and Sources}

The data type in this research is quantitative, namely data in the form of non-verbal which can be measured and calculated directly in the form of numbers. Sources of data are in the form of a questionnaire given to respondents and data on the general description of the institution obtained from the respondents.

\subsection{Population}

The population in this study were all Regional Apparatus Organizations (OPD) in Donggala Regency, amounting to 51 OPD.

\subsection{Research Sample}

Sampling of the respondents was carried out using the purposive sampling method. The criteria set are Regional Apparatus Organizations which are accounting entities and OPDs that have a budget ceiling above 2 billion. This is because if the budget ceiling is higher, then the government agency has a wider and more complex work program in managing its finances. Based on these criteria, the sample in this study amounted to 30 OPD involving 60 respondents who are OPD leaders and the Head of Finance/Treasury Subdivision.

\subsection{Data Collection Technique}

Collecting data was conducted by using a questionnaire. In addition to questionnaires, data collection techniques were also be done by interviewing.

\subsection{Instrument Testing}

\subsubsection{Validity Test}

Validity test is used to measure statements or questions in the questionnaire. Validity test is used by connecting each statement with the total score. An indicator is declared valid or included in the good category if the outer loading value is $>0.60$ and is considered significant if the p-value is $<0.05$.

\subsubsection{Reliability Test}

The construct reliability test can be measured by two criteria, namely composite reliability and Cronbach' Alpha. A construct is declared reliable if it shows a composite reliability value $>0.70$, and a construct is said to be reliable if the reliability value is high, which is assessed with a reliability coefficient ranging from $0-1$.

\subsubsection{Hypothesis Test}

Hypothesis testing is used to explain the direction of the relationship between the independent variable and the dependent variable. This test was carried out with a p-value of 0.05 .

\section{RESULTS AND DISCUSSION}

\subsection{Research Instrument Testing Results}

Table 1 showed the testing results of the validity and reliability of the research instrument. It is intended so that the list of questions in the instrument used can collect valid and reliable research data.

Table 1. Validity Test Results

\begin{tabular}{|c|c|c|c|}
\hline Variable & $\begin{array}{l}\text { AVE } \\
\text { Value }\end{array}$ & Criteria & Information \\
\hline $\begin{array}{l}\text { Aperture } \\
\text { Competence }\end{array}$ & 0,506 & $>0,50$ & Valid \\
\hline $\begin{array}{l}\text { Utilization } \\
\text { Information } \\
\text { Technology }\end{array}$ & 0,504 & $>0,50$ & Valid \\
\hline $\begin{array}{ll}\text { Financial } & \text { Report } \\
\text { Quality } & \end{array}$ & 0,520 & $>0,50$ & Valid \\
\hline
\end{tabular}

Source: Data processed by researchers, 2020

Based on Table 1, each variable has an AVE value $>0.50$, so it can be declared valid. The reliability test can be strengthened by Cronbach alpha $>0.6$. 
Table 2. Value of Cronbach's alpha Coefficients

\begin{tabular}{|l|c|c|c|}
\hline \multicolumn{1}{|c|}{ Variable } & $\begin{array}{c}\text { Composite } \\
\text { Reliability } \\
\text { Value }\end{array}$ & Criteria & Information \\
\hline $\begin{array}{l}\text { Apparatus } \\
\text { Competence }\end{array}$ & 0.891 & $>0.60$ & Reliable \\
\hline $\begin{array}{l}\text { Utilization of } \\
\text { Information } \\
\text { Technology }\end{array}$ & 0.890 & $>0.60$ & Reliable \\
\hline $\begin{array}{l}\text { Financial Report } \\
\text { Quality }\end{array}$ & 0.906 & $>0.60$ & Reliable \\
\hline
\end{tabular}

Source: Data processed, 2020

Based on Table 2, it can be concluded that all variables in this study have met the reliability criteria. Next, test the fit of the model to determine the causal relationship between latent variables. In the model fit test, there are 3 test indices, namely average path coefficient (APC), Average R-Squared (ARS) and Average Variance Factor (AVIF) with APC and ARS criteria accepted provided that $\mathrm{p}$-Value $<0.05$ and AVIF is smaller out of 5 [14]. The results of the model fit test in this study can be seen in Table 3 .

Table 3. Model Fit Test

\begin{tabular}{|c|}
\hline Model fit and quality indices \\
\hline Average path coefficient $(\mathrm{APC})=0.412, \mathrm{P}<0.001$ \\
\hline Average $\mathrm{R}$-squared $(\mathrm{ARS})=0.589, \mathrm{P}<0.001$ \\
\hline Average adjusted $\mathrm{R}$-squared (AARS) $=0.569, \mathrm{P}<0.001$ \\
\hline $\begin{array}{l}\text { Average block VIF (AVIF)=1.861, acceptable if }<=5 \text {, } \\
\text { ideally }<=3.3\end{array}$ \\
\hline $\begin{array}{l}\text { Average full collinearity VIF (AFVIF) }=2.264 \text {, acceptable if } \\
<=5 \text {, ideally }<=3.3\end{array}$ \\
\hline
\end{tabular}

Source: Output model fit and quality indices Warp PLS. 6.0

Table 3 showed that the average path coefficient (APC) index is 0.412 with a p-value of $<0.001$ less than 0.05. The Average R-Squared Index (ARS) is 0.589 with a p-value $<0.001$ less than 0.05 , and AVIF value is $1.861<5.0$. The test results mean that the criteria for testing the suitability of the model in this study have been met, so that the inner model can be accepted.

\subsection{Hypothesis Testing Results}

The results of hypothesis testing in this study can be seen in Figure 2 and Figure 3.

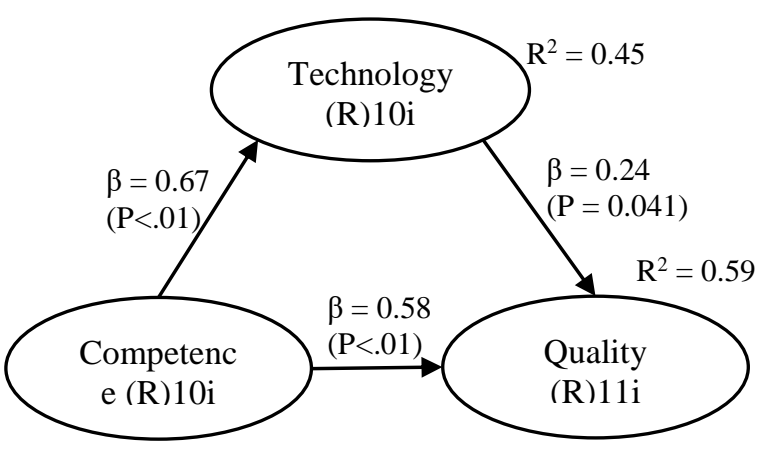

Source: Output SEM Model Warp PLS. 6.0

Figure 2. H1 SEM Test Results

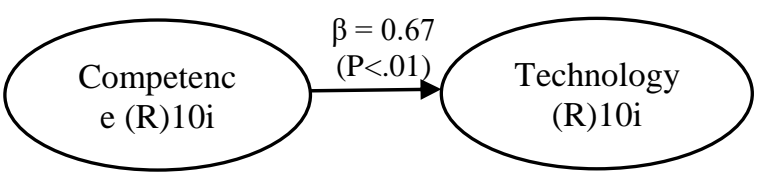

Source: Output SEM Model Warp PLS. 6.0

Figure 3. H2 SEM Test Results

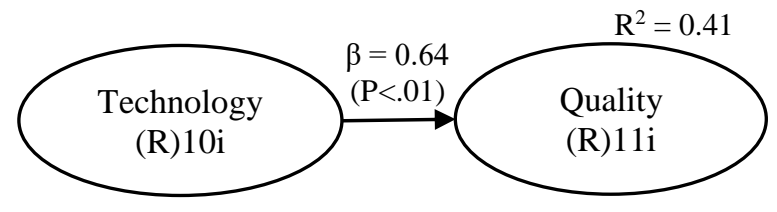

Source: Output SEM Model Warp PLS. 6.0

Figure 4. H3 SEM Test Results

The test results in this study are based on the results of the path analysis in the table which are summarized in Table 4.

Table 4. Hypothesis Testing Results

\begin{tabular}{|l|c|c|c|}
\hline \multicolumn{1}{|c|}{ Variable } & \multicolumn{1}{c|}{$p^{-}$} & $\begin{array}{c}\text { Criteria } \\
\text { values } \\
\text { p-values }\end{array}$ & Information \\
\hline $\begin{array}{l}\text { Apparatus } \\
\text { Competence }\end{array}$ & 0.001 & $<0,05$ & Accepted \\
\hline $\begin{array}{l}\text { Utilization of } \\
\text { Information } \\
\text { Technology }\end{array}$ & 0.001 & $<0,05$ & Accepted \\
\hline
\end{tabular}

Source: Output Define SEM Model Warp PLS. 6.0

a) The apparatus competency variable (X1) obtained p-value with a significance level smaller than $5 \%$, namely $0.001<0.05$. Therefore, the apparatus competence variable $(\mathrm{X})$ has a significant effect on the quality of financial reports (Y) with the use of technology $(Z)$ as an intervening variable. Based on the results, the hypothesis that the competence of the apparatus affects the quality of financial 
reports with the use of information technology as an intervening variable is accepted.

b) Apparatus competency (X) obtained p-value with a significance level smaller than 5\%, namely 0.001 $<0.05$. So, the second hypothesis of this study, where the competence of the apparatus (X) partially affects the utilization of information technology $(\mathrm{Z})$ is accepted.

c) Information technology $(\mathrm{Z})$ have a significant $\mathrm{p}$ value smaller than $5 \%$, namely $0.001<0.05$. So, the third hypothesis stating that information technology (Z) partially affects the quality of regional financial reports $(\mathrm{Y})$ is accepted.

\section{DISCUSSION}

\subsection{Apparatus Competence Affects the Quality of Financial Reports by Utilizing Information Technology as an Intervening Variable}

The results of hypothesis testing indicate that the variable of apparatus competence has a significant effect on the quality of financial reports with the use of information technology as an intervening variable in OPD in Donggala Regency. This means that the higher the competence of the apparatus and the higher the technological facilities that support the OPD, the higher the quality of financial reports will increase. The results of this study are in accordance with research conducted by Ramadan [15] which confirms that good quality financial reports will provide dedication to accountability or responsibility for the financial statements made.

\subsection{Apparatus Competence Partially Affects the Utilization of Technology in Regional Apparatus Organizations}

The results indicate that the higher the competency value of the apparatus, the higher the utilization of information technology in regional apparatus organizations. Thus, the second hypothesis, namely the competence of the apparatus partially affects the use of information technology, is empirically proven to be accepted. The competence of the apparatus in operating information technology is very important. This is related to the apparatus as human resources who apply the technology.

\subsection{Information Technology Partially Affects the Quality of Regional Financial Reports}

The results of hypothesis testing show that the use of information technology affects the quality of financial reports at OPD in Donggala Regency. Information technology variable affect the quality of financial reports. The results indicate that the role of information technology has a significant effect on the quality of local government financial reports. The results show that the use of information technology by employees in the preparation of local government financial reports has been utilized. The results of this study are in line with the results of research conducted by [10] empirically proving that the use of information technology affects the quality of local government financial reports. The higher the utilization of information technology, the better the quality of financial reports. On the other hand, if the use of information technology decreases, the quality of local government financial reports will also decrease. In the description of the information technology variable, it is stated that the internet network has been used as a liaison between work units in sending data and information needed, meaning that an integrated information system has been determined by the OPD.

\section{CONCLUSION}

The conclusion of the study found that 1) apparatus competence has a significant effect on the quality of OPD financial reports in Donggala Regency with the use of information technology as an intervening variable. This shows that the higher the competence of the apparatus and the higher the technological facilities that support the OPD, the quality of financial reports will increase. 2) The competence of the apparatus partially affects the use of information technology. This is related to the apparatus as human resources that apply information technology with the achievement of several indicators including employee skills in applying computers. 3) Information technology partially affects the quality of regional financial reports. This shows that the use or utilization of information technology improves the quality of financial reports.

\subsection{Suggestion}

Donggala OPD employees should apply limit determination and determination of tolerance for employee work. For the OPD of Donggala Regency, in producing quality financial reports, it is better if damaged computer equipment is immediately recorded and repaired so as to support the use of information technology in producing financial reports.

As limitation, some respondents were received external assignments or were not in place, so that some questionnaires were returned late, and some did not even return. Researchers have tried to send a questionnaire in the form of a google form, but only a few respondents were willing to fill out the 
questionnaire. Future researchers are expected to be able to expand and develop the results of this study, especially related to the variables that affect the quality of financial reports.

\section{AUTHORS' CONTRIBUTIONS}

First Author: writing, data analysis and field research; Second and third authors: method, data analysis; Fourth, fifth, sixth and seventh authors: validation.

\section{ACKNOWLEDGMENTS}

Thanks to Tadulako University for providing research and financial support, and to the conference committee for providing the opportunity to present this article.

\section{REFERENCES}

[1] I. Salamah, "Pemanfaatan Sistem Informasi dan Teknologi Informasi Pengaruhnya Terhadap Kinerja Individual Karyawan," J. Akunt. dan Keuang., vol. 14, no. 1, 2012, pp. 56-68,

[2] I. P. (2021). Astuti, "The role of financial inclusion in poverty reduction: A production theory approach," Res. Horiz., vol. 1, no. 5, 2021.

[3] N. Indriasari, Pengaruh kapasitas sumberdaya manusia, pemanfaatan teknologi informasi, dan pengendalian intern akuntansi terhadap nilai informasi pelaporan keuangan pemerintah daerah (studi pada pemerintah kota palembang dan kabupaten ogan ilir). Pontianak: SNA XI Pontianak, 2008.

[4] F. C. Pradono and Basukianto, "Kualitas Laporan Keuangan Pemerintah Daerah: Faktor yang mempengaruhi dan Implikasi Kebijakan (Studi Pada SKPD Pemerintah Provinsi Jawa Tengah)," J. Bisnis Dan Ekon., vol. 22, no. 2, 2015. pp. 188-200.

[5] M. Fakhimuddin, U. Khasanah, and R. Trimiyati, "Database Management System in Accounting: Assessing the role of Internet Service Communication of Accounting System Information," Res. Horiz., vol. 1, no. 3, 2021, pp. 100-105.

[6] N. Soetjipto, G. Kurniawan, S. Sulastri, and A. Riswanto, "The Influence of Employee Discipline, Learning and Supervision on the Service Performance of Public Works in Bina Marga Office of Ponorogo Regency," Res. Horiz., vol. 1, no. 4, 2021, pp. 143-149.

[7] A. Thalib, Pengaruh Kompetensi Aparatur terhadap Kualitas Laporan Keuangan pada
Kantor Kementerian Agama Kabupaten Gorontalo. Gorontalo: Universitas Negeri Gorontalo, 2012.

[8] N. Zubaidi, D. Cahyono, and A. Maharani, "Pengaruh Kompetensi Sumber Daya Manusia dan Pemanfaatan Teknologi Informasi terhadap Kualitas Laporan Keuangan," Int. J. Soc. Sci. Bus., vol. 3, no. 2, 2019, pp. 68-76.

[9] R. Y. G. Armel, A. Nasir, and D. Safitri, Pengaruh Kompetensi Sumber Daya Manusia, Penerapan Standar Akuntansi Pemerintahan, Pemanfaatan Teknologi Informasi dan Sistem Pengendalian Internal terhadap Kualitas Laporan Keuangan Pemerintah Daerah (Studi pada Satuan Kerja Perangkat Daerah Kota Dumai). Riau: Riau University, 2017.

[10] I. B. Pamungkas, "Pengaruh Sistem Informasi Manajemen, Kompetensi, Motivasi Terhadap Kinerja Karyawan Pada PT. Circleka Indonesia Utama (Wilayah Jakarta)," Kreat. J. Ilm. Prodi Manaj. Univ. Pamulang, vol. 5, no. 1, 2017, pp. $18-29$.

[11] H. Hardiansyah, Pengaruh Kompetensi Sumber Daya Manusia Dan Pemanfaatan Teknologi Informasi Terhadap Kualitas Laporan Keuangan Dengan Sistem Pengendalian Intern Sebagai Variabel Moderasi Pada Skpd Kabupaten Polewali Mandar. Makassar: Universitas Islam Negeri Alauddin, 2016.

[12] S. P. Hariningsih, Teknologi Informasi. Yogyakarta: Graha Ilrnu, 2005.

[13] J. K. Thompson, L. Heinberg, and S. TantleffDunn, "The physical appearance comparison scale," Behav. Ther., vol. 14, 1991, pp. 174.

[14] M. Sholihin and D. Ratmono, Analisis SEM-PLS dengan WarpPLS 3.0 untuk Hubungan Nonlinier dalam Penelitian Sosial dan Bisnis. Yogyakarta: Andi Offset, 2013.

[15] I. Z. Ramadan, "The Impact of Institutional investors on firms accounting flexibility: evidence from Jordan," Int. J. Econ. Financ., vol. 4, no. 6, 2012, pp. 141-148. 